\title{
Arsenite induces DNA damage via mitochondrial ROS and induction of mitochondrial permeability transition
}

\author{
Andrea Guidarelli, Mara Fiorani, Liana Cerioni, Maddalena Scotti and Orazio Cantoni* \\ Dipartimento di Scienze Biomolecolari, Università degli Studi di Urbino “Carlo Bo”, 61029 \\ Urbino, Italy
}

*Address for correspondence: Prof. Orazio Cantoni, Dipartimento di Scienze Biomolecolari, Sezione di Farmacologia e Farmacognosia, Università degli Studi di Urbino, Via S. Chiara 27, 61029 Urbino (PU), Italy. Tel: +39-0722-303523; e-mail: orazio.cantoni@uniurb.it

Abbreviations: AA, L-ascorbic acid; ATZ, 3-amino-1,2,4,-triazole; CsA, cyclosporin A; DHR, dihydrorhodamine 123; EDTA, ethylenediaminetetraacetic acid; EB, extracellular buffer; $\mathrm{H}_{2} \mathrm{O}_{2}$, hydrogen peroxide; HPLC, high performance liquid chromatography; $\mathrm{MitoO}_{2}^{-}$, mitochondrial $\mathrm{O}_{2} \cdots$; MPT, mitochondrial permeability transition; NO, nitric oxide; PBS, phosphate-buffered saline; RD cells, respiration-deficient cells; ROS, reactive oxygen species; RNS, reactive nitrogen species; Rot, rotenone; $\mathrm{O}_{2}{ }^{--}$, superoxide; SVCT, sodium-AA co-transporter 


\section{Summary}

Arsenite is an established DNA-damaging agent and human carcinogen. We initially selected conditions in which the metalloid causes DNA strand scission in the absence of detectable apoptotic DNA degradation in U937 cells. This response was suppressed by catalase and by treatments (rotenone and ascorbic acid), or manipulations (respirationdeficient phenotype), preventing the mitochondrial formation of $\mathrm{O}_{2}^{-\cdot}\left(\operatorname{mitoO}_{2}^{-\cdot}\right)$. $\mathrm{MitoO}_{2}^{-\cdot}$, and its dismutation product, $\mathrm{H}_{2} \mathrm{O}_{2}$, are therefore critically involved in the arsenite-dependent DNA-damaging response. We then established a link between $\operatorname{mitoO}_{2}^{-} \cdot / \mathrm{H}_{2} \mathrm{O}_{2}$ and mitochondrial permeability transition (MPT), and found that this second event also promoted the formation of DNA-damaging species. As a consequence, the DNA damage induced by arsenite, in addition to being abolished by the above-mentioned treatments/manipulations, was also significantly reduced by the MPT inhibitor cyclosporin A (CsA). A CsA-sensitive induction of p53 mRNA expression was also detected. Finally, evidence of CsA-sensitive DNA strand scission was also obtained in MCF-7, HT22 and NCTC-2544 cells.

$\mathrm{MitoO}_{2}{ }^{-\cdots} / \mathrm{H}_{2} \mathrm{O}_{2}$ therefore directly mediates DNA damage induced by arsenite and indirectly promotes the formation of additional DNA-damaging species via the induction of MPT.

Keywords: Arsenite, Mitochondrial superoxide, Mitochondrial permeability transition, Hydrogen peroxide, DNA strand scission 
Running Title: A role for cyclosporin A-sensitive ROS in arsenite-induced DNA damage

\section{Introduction}

Arsenic is widely distributed in water, soil and food in various parts of the world, and endemic exposure to the element poses a serious threat to millions of people. The metalloid is a potential trigger of an array of adverse health effects, including cardiovascular and neurological diseases, as well as various forms of cancers (e.g., bladder, liver, kidney and skin cancers) $(1,2)$.

The carcinogenic effects of arsenite are most likely attributable to the convergence of complex mechanisms (1-3), in particular, those involved in the genotoxic response, which have been documented in numerous reports (4-16). The mechanism whereby arsenite promotes the formation of DNA lesions has also been extensively investigated, and it is generally believed that this response is linked to the parallel formation of reactive oxygen/nitrogen species (ROS/RNS) (5-11,14-16). Specifically, it has been reported that DNA damage induced by arsenite is mediated by peroxynitrite, the coupling product of nitric oxide (NO) and superoxide $\left(\mathrm{O}_{2}^{-}\right)$. Indeed, pioneering work by Tom Hei's (11) group demonstrated that the mutagenicity of arsenite in human-hamster hybrid cells is mediated by reactive species, in particular, peroxynitrite, which requires $\mathrm{O}_{2}{ }^{-}$for its formation. Under the specific experimental conditions, $\mathrm{O}_{2}^{-}$. was generated at the mitochondrial level as a consequence of mitochondrial dysfunction. This mechanism, leading to the formation of peroxynitrite, carries additional important consequences in terms of potential downstream effects elicited by arsenite at the level of gene expression, in particular, when specific cell types, such as the endothelium, are involved (17).

Mitochondrial $\mathrm{O}_{2}^{-\cdot}\left(\mathrm{mitoO}_{2}^{-\cdot}\right)$ is therefore a potential, indirect cause of arsenite-dependent DNA strand scission in NO synthase (constitutive and inducible) expressing cells, but likely mediates the same response in the absence of NO through an additional mechanism. Indeed, 
mitoO ${ }_{2}^{-\cdot}$ readily dismutates, spontaneously or enzymatically, to hydrogen peroxide $\left(\mathrm{H}_{2} \mathrm{O}_{2}\right)$, which, being diffusible, can reach distal sub-cellular targets, including the nucleus. DNA strand scission can therefore finally be induced through the site-specific formation of highly reactive hydroxyl radicals in a Fenton-type reaction, i.e., mediated by the interaction of $\mathrm{H}_{2} \mathrm{O}_{2}$ with divalent iron. Although some evidence points to this possibility $(6,8,9)$, a definitive demonstration univocally linking these latter events to upstream mitoO ${ }_{2}^{-\cdot}$ formation is still lacking.

Having previously demonstrated that, in the specific U937 cell clone employed in our laboratory, arsenite exclusively promotes $\operatorname{mitoO}_{2}^{-\cdot}$ formation, with hardly any contribution mediated by other mechanisms $(18,19)$, we decided to attempt to fill the gap left by previous investigations. For this purpose, we took advantage of the observations that $\mathrm{O}_{2}{ }^{-}$formation is suppressed by specific respiratory chain inhibitors and is not detected in cells manipulated to induce respiration-deficiency $(18,19)$. Likewise, the release of $\mathrm{O}_{2}^{-\cdot}$ was selectively suppressed by pre-exposing the cells to a very low concentration of L-ascorbic acid (AA) (18), a condition however associated with a significant mitochondrial accumulation of the vitamin (20-22), attributable to the very high expression of high affinity AA transporters (SVCT2) in both the plasma and mitochondrial membranes of the cell clone employed (21).

Our previous studies on arsenite toxicity in U937 cells have shown that the process of $\mathrm{mitoO}_{2}^{-}$formation is also critical for the induction of mitochondrial permeability transition (MPT) and for the ensuing apoptosis $(18,23)$. We therefore decided to investigate the possibility that MPT, through the release of additional reactive species, may amplify the overall oxidative stress and contribute to the initial genotoxic response. This investigation, for the reasons detailed above, was conducted on the same cell line employed in our previous studies involving the use of cyclosporin A (CsA). CsA prevents MPT through inhibition of cyclophilin D, i.e., via a mechanism unrelated to the immunosuppressive effects of the drug, but rather linked to the inhibition of calcineurin (24). FK-506 (tacrolimus), which shares with 
CsA only this calcineurin inhibiting effect, can therefore be used to establish the specificity of the effects of CsA as an MPT inhibitor (25).

The results presented herein show that $\mathrm{mitoO}_{2} \cdot$ generated by arsenite is converted to $\mathrm{H}_{2} \mathrm{O}_{2}$, which, being diffusible, migrates to the nucleus and induces site-specific DNA damage. $\mathrm{MitoO}_{2}-/ \mathrm{H}_{2} \mathrm{O}_{2}$, however, also indirectly contributes to DNA strand scission via the induction of MPT, resulting in CsA-sensitive formation of additional reactive oxygen species. Under these conditions, the cells preserved an intact ATP pool and responded with increased p53 mRNA expression. The CsA-sensitive DNA lesions induced by arsenite were also detected in MCF-7, HT22 and NCTC-2544 cells. 


\section{Experimental Procedures}

\subsection{Chemicals}

Sodium arsenite, rotenone (Rot), AA, Hoechst 33342, $\mathrm{H}_{2} \mathrm{O}_{2}, 3$-amino-1,2,4,-triazole (ATZ), as well most of the reagent-grade chemicals were purchased from Sigma-Aldrich (Milan, Italy). Cyclosporin A (CsA) was from Novartis (Bern, Switzerland). FK-506 was obtained from Calbiochem (San Diego, CA). Dihydrorhodamine 123 (DHR) and MitoTracker Red CMXRos were purchased from Molecular Probes (Leiden, The Netherlands).

\subsection{Cell culture and treatment conditions}

U937 human myeloid leukemia cells were cultured in suspension in RPMI 1640 medium (Sigma-Aldrich). MCF-7 human breast carcinoma cells, HT22 immortalized mouse hippocampal cells and NCTC-2544 human keratinocytes cells were grown in Dulbecco's modified Eagle medium (Sigma-Aldrich). Culture media were supplemented with $10 \%$ fetal bovine serum (Euroclone, Celbio Biotecnologie, Milan, Italy), penicillin (100 units $/ \mathrm{ml}$ ) and streptomycin $(100 \mu \mathrm{g} / \mathrm{ml})$ (Euroclone). Cells were grown at $37{ }^{\circ} \mathrm{C}$ in $\mathrm{T}-75$ tissue culture flasks (Corning Inc., Corning, NY) gassed with an atmosphere of $95 \%$ air-5\% $\mathrm{CO}_{2}$. The U937 cells were made respiration-deficient (RD cells) as indicated in (26). Sodium arsenite was prepared as a $1 \mathrm{mM}$ stock solution in saline A $(8.182 \mathrm{~g} / \mathrm{l} \mathrm{NaCl}, 0.372 \mathrm{~g} / \mathrm{l} \mathrm{KCl}, 0.336 \mathrm{~g} / \mathrm{l}$ $\mathrm{NaHCO}_{3}$, and $0.9 \mathrm{~g} / \mathrm{l}$ glucose, $\left.\mathrm{pH} 7.4\right)$ and stored at $4^{\circ} \mathrm{C}$. Cells $\left(1 \times 10^{5}\right.$ cells $\left./ \mathrm{ml}\right)$ were exposed to arsenite in complete RPMI 1640 culture medium, as reported in the legends to the figures. In experiments involving catalase depletion, the cells $\left(5 \times 10^{6} / 20 \mathrm{ml}\right)$ were incubated for $6 \mathrm{~h}$ at

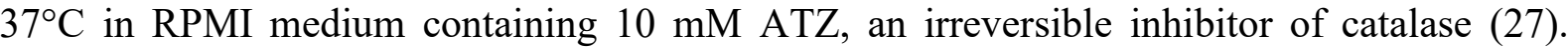
Experiments with $\mathrm{H}_{2} \mathrm{O}_{2}$ were performed using $15 \mathrm{ml}$ plastic tubes containing $5 \times 10^{5}$ cells in 2 $\mathrm{ml}$ of pre-warmed saline A. A $10 \mathrm{mM}$ AA stock solution was prepared in extracellular buffer (EB, $15 \mathrm{mM}$ Hepes, $135 \mathrm{mM} \mathrm{NaCl}, 5 \mathrm{mM} \mathrm{KCl}, 1.8 \mathrm{mM} \mathrm{CaCl}_{2}, 0.8 \mathrm{mM} \mathrm{MgCl}, \mathrm{pH} 7.4$ ) 
immediately before use. Cells $\left(1 \times 10^{6}\right.$ cells $\left./ \mathrm{ml}\right)$ were treated with AA supplemented with 0.1 $\mathrm{mM}$ dithiothreitol for $15 \mathrm{~min}$ at $37^{\circ} \mathrm{C}$ in $\mathrm{EB}$. Stability of $\mathrm{AA}$ in $\mathrm{EB}$ was assessed by monitoring the absorbance at $267 \mathrm{~nm}$ for $15 \min \left(\varepsilon_{267}=14,600 \mathrm{M}^{-1} \mathrm{~cm}^{-1}\right)$.

\subsection{Alkaline-halo assay}

DNA single-strand breakage was determined using the alkaline halo assay developed in our laboratory (28). It is important to bear in mind that, although we refer to DNA strand scission throughout the text, the DNA nicks measured by this technique under alkaline conditions may in fact include alkali labile sites in addition to direct strand breaks. Details on the alkaline halo assay and processing of fluorescence images and on the calculation of the experimental results are also provided in Ref. (28). DNA single-strand breakage was quantified by calculating the nuclear spreading factor value, representing the ratio between the area of the halo (obtained by subtracting the area of the nucleus from the total area, nucleus + halo) and that of the nucleus, from 50 to 75 randomly selected cells/experiment/treatment condition. Results are expressed as relative nuclear spreading factor values calculated by subtracting the nuclear spreading factor values of control cells from those of treated cells.

\subsection{Comet assay}

The comet assay was performed as described in Ref. (29). After treatments, the cells $(2.0 \mathrm{x}$ $10^{4}$ cells $\left./ 100 \mu \mathrm{l}\right)$ were resuspended at $2.0 \times 10^{4}$ cells $/ 100 \mu \mathrm{l}$ in $1.0 \%$ low-melting agarose in PBS containing $5 \mathrm{mM}$ ethylenediaminetetraacetic acid (EDTA) and immediately pipetted into agarose-coated slides. The slides were immersed in ice-cold lysing solution $(2.5 \mathrm{M} \mathrm{NaCl}, 100$ mM EDTA, $10 \mathrm{mM}$ Tris, $1 \%$ sarkosyl, 5\% dimethyl sulfoxide, and 1\% Triton $\mathrm{X}-100, \mathrm{pH}$ 10.0) for $60 \mathrm{~min}$. The slides were placed on an electrophoresis tray with an alkaline buffer (300 $\mathrm{mM} \mathrm{NaOH}$ and $1 \mathrm{mM}$ EDTA) and left for $20 \mathrm{~min}$ to allow the DNA to unwind; electrophoresis was then performed at $300 \mathrm{~mA}$ for $20 \mathrm{~min}$ in the same alkaline buffer 
maintained at $14{ }^{\circ} \mathrm{C}$. The slides were subsequently washed and stained for 5 min with 10 $\mu \mathrm{g} / \mathrm{ml}$ ethidium bromide. The DNA was visualized by a fluorescence microscope (BX-51, Olympus, Milan, Italy), equipped with a SPOT-RT camera unit (Diagnostic Instruments, Delta Sistemi, Rome, Italy) using an Olympus LCAch 40 x/0.55 objective lens. Mean fluorescence values were determined by averaging the fluorescence values of at least 50 cells/treatment condition/experiment.

\subsection{Identification of apoptosis with Hoechst 33342}

After treatments, the cells were incubated for $5 \mathrm{~min}$ with the cell-permeable DNA dye (Hoechst 33342, $10 \mu \mathrm{mol} / \mathrm{l}$ ) and then analysed with a fluorescence microscope to assess their nuclear morphology (chromatin condensation and fragmentation). Cells with homogeneously stained nuclei were considered viable.

\subsection{Immunofluorescence analysis}

After treatments, the cells were suspended in $2 \mathrm{ml}$ of saline A and incubated for $30 \mathrm{~min}$ in 35-mm tissue culture dishes containing an uncoated coverslip. Under these conditions, cells rapidly attach to the coverslip. The cells were then fixed for 1 min with $95 \%$ ethanol/5\% acetic acid, washed with phosphate buffer saline (PBS, 8 g/l NaCl, 1.15 g/l Na $2 \mathrm{HPO}_{4}, 0.2 \mathrm{~g} / 1$ $\left.\mathrm{KH}_{2} \mathrm{PO}_{4}, 0.2 \mathrm{~g} / \mathrm{l} \mathrm{KCl}, \mathrm{pH} 7.4\right)$ and blocked in PBS containing bovine serum albumin $(2 \% \mathrm{w} / \mathrm{v})$ for $30 \mathrm{~min}$ at room temperature. The cells were subsequently incubated with rabbit polyclonal anti-cleaved caspase-3 antibody (1:250 in PBS containing 2\% bovine serum albumin; Cell Signaling Technology, \#9661) or with rabbit polyclonal anti-cytochrome c antibody (1:100 in PBS containing $2 \%$ bovine serum albumin; Santa Cruz Biotechnology) stored for $18 \mathrm{~h}$ at $4{ }^{\circ} \mathrm{C}$, washed and then exposed to fluorescein isothiocyanate (Santa Cruz Biotechnology)conjugated secondary antibody diluted $1 / 100$ in PBS for $2 \mathrm{~h}$ in the dark. Stained cells were 
captured with a fluorescence microscope and the resulting images were processed for fluorescence determination as described above.

\subsection{DHR oxidation}

The cells were incubated for 30 min with $10 \mu \mathrm{M}$ DHR prior to the end of the $16 \mathrm{~h}$ incubation with arsenite. After treatments, the cells were washed three times with saline A and analyzed with a fluorescence microscope. The excitation and emission wavelengths were 488 and 515 $\mathrm{nm}$ with a 5-nm slit width for both emission and excitation. The resulting images were acquired and processed as described above. Images were collected with exposure times of 100-400 ms, digitally acquired and processed for fluorescence determination at the single cell level on a personal computer using J-Image software. Mean fluorescence values were determined by averaging the fluorescence values of at least 50 cells/ treatment condition/experiment.

\subsection{MitoTracker Red CMXRos, calcein staining and imaging}

The cells were incubated for 30 min with $50 \mathrm{nM}$ MitoTracker Red CMXRos prior to the end of the $16 \mathrm{~h}$ incubation with arsenite. In other experiments the cells were incubated for 15 min with $1 \mu \mathrm{M}$ calcein-AM and $1 \mathrm{mM} \mathrm{CoCl} 2$ prior to the end of the $16 \mathrm{~h}$ incubation with arsenite. After treatments, the cells were washed three times and analyzed with a fluorescence microscope. The resulting images were acquired and processed as described above. The excitation and emission wavelengths were 488 and $515 \mathrm{~nm}$ (calcein) and 545 and $610 \mathrm{~nm}$ (MitoTracker Red CMXRos), with a 5-nm slit width for both emission and excitation. Images were collected with exposure times of 100-400 ms, digitally acquired and processed for fluorescence determination at the single cell level on a personal computer using J-Image software. Mean fluorescence values were determined by averaging the fluorescence values of at least 50 cells/treatment condition/experiment. 


\subsection{ATP determination}

Ice-cold 5\% perchloric acid was added to the cells $\left(2 \times 10^{6}\right.$ cells $)$. After a $10 \mathrm{~min}$ incubation in an ice bath, the samples were centrifuged for $5 \mathrm{~min}$ at $10,000 \mathrm{~g}$. The supernatants were neutralized with $3 \mathrm{M} \mathrm{K}_{2} \mathrm{CO}_{3}$, and the precipitates were removed by centrifugation. $10 \%(\mathrm{v} / \mathrm{v}) 1 \mathrm{M} \mathrm{KH}_{2} \mathrm{PO}_{4}(\mathrm{pH}$ 6.5) was added to the nucleotide-containing supernatants. The samples were then filtered through $0.22 \mu \mathrm{m}$ pore micro-filters and analyzed for ATP content by reversed-phase high-performance liquid chromatography (30) using a 15 cm x4.6 mm, 5 um Supelco Discovery® C18 column (Supelco, Bellefonte, PA).

\subsection{RNA extraction, reverse transcription and quantitative real-time PCR}

Cells treated for $12 \mathrm{~h}$ with 2.5 arsenite were processed for total RNA extraction using TRIzol reagent (Invitrogen, Carlsbad, CA) according to the manufacturer's instructions. The amount of RNA extracted was quantified with a spectrophotometer (NanoDrop ND-1000, NanoDrop Technologies, Wilmington, DE). $1 \mu \mathrm{g}$ of total RNA was pre-treated with DNAse I (Sigma-Aldrich) and used for cDNA synthesis with the SMARTScribe Reverse Transcriptase (Clontech Laboratories, Mountain View, CA). Gene expression was measured by quantitative real-time PCR using Rotor-gene 6000 System (Corbett Life Science, Concorde, NSW, Australia) and EvaGreen ${ }^{\circledR}$ dye (Biotium, Inc., Fremont, CA). cDNA was added to a $2 \mathrm{X}$ PCR Master Mix Kit solution (Diatheva srl, Fano, Italy) containing $100 \mathrm{nM}$ of each primer. The final volume of the mixture was $25 \mu 1$. All reactions involved an initial denaturation step at 95 ${ }^{\circ} \mathrm{C}(8 \mathrm{~min})$, followed by 40 cycles at $95^{\circ} \mathrm{C}$ for $15 \mathrm{~s}$ and $58{ }^{\circ} \mathrm{C}$ for $45 \mathrm{~s}$. Relative gene expression was determined using the $\Delta \Delta \mathrm{CT}$ method normalized to GAPDH as the reference gene (31). The list of primers is: p53 For 5'-CCTCACCATCATCACACTGG-3', Rev 5'GCGGAGATTCTCTTCCTCTG-3'; GAPDH For 5'-TGCACCACCAACTGCTTAG-3', Rev 5'-GATGCAGGGATGATGTTC-3'. 


\subsection{Statistical analysis}

The results are expressed as means \pm SD. Statistical differences were analyzed by one-way ANOVA followed by Dunnett's test for multiple comparison or two-way ANOVA followed by Bonferroni's test for multiple comparison. A value of $P<0.05$ was considered significant. 


\section{Results}

\subsection{Arsenite induces early DNA strand scission independently of the apoptotic DNA fragmentation}

Logarithmically growing U937 cells were first exposed for $16 \mathrm{~h}$ to $1-5 \mu \mathrm{M}$ arsenite and then processed for the analysis of DNA strand breakage using two separate and independent techniques, the alkaline halo and the comet assays, allowing the detection of these lesions at the single cell level with a similar sensitivity (28). The results obtained (Fig. 1A) are indicative of a concentration-dependent induction of DNA damage. As these assays were performed at alkaline $\mathrm{pH}$, the lesions detected are potentially represented by DNA single- and double-strand breaks as well as by alkali-labile sites, readily converted to DNA strand breaks under alkaline conditions. In principle, the DNA fragmentation occurring during apoptosis may also be detected, thereby introducing a bias for the correct interpretation of the experimental results. This is particularly true in the case of the halo assay, which does not allow a clear-cut distinction between cells with a heavily damaged DNA and cells with an ongoing apoptotic DNA fragmentation. The comet assay, on the contrary, is suitable for discriminating between these two cell populations, as the electrophoresed DNA of the apoptotic cells appears as a pear-shaped comet tail with a very small (or non existing) head (nuclear remnant). Fig. 1B provides a typical image of a DNA migration pattern indicative of genotoxicity. Most of the cells grown for $16 \mathrm{~h}$ in the presence of $2.5 \mu \mathrm{M}$ arsenite resulted in a similar DNA migration pattern, whereas the remaining cells presented an undamaged/very slightly damaged DNA (Fig. 1C). Occasionally, very few pear-shaped comets were observed, although the same was true also for the untreated cells. A significant proportion of cells presenting the apoptotic DNA migration pattern, exemplified in Fig. 1D, was instead detected after a $48 \mathrm{~h}$ exposure to the metalloid, a condition associated with the appearance of apoptotic cells (see below). Using this criterion, about $15 \%$ of the cells resulted apoptotic, whereas the percentage dropped down to less than $5 \%$ in the untreated cell population (Fig. 1E). 
The above-mentioned results indicate that a $16 \mathrm{~h}$ exposure to $2.5 \mu \mathrm{M}$ arsenite causes an extensive DNA damage attributable to a genotoxic response, a conclusion consistent with our previous findings indicating that, under identical conditions, all the cells remain viable $(18,19)$. Along the same lines is the observation that the metalloid fails to increase the number of cells displaying fragmented and condensed chromatin, as detected by the Hoechst assay (Fig. 1F), or cleaved caspase 3 (Fig. 1G). Both responses were instead detected at later time intervals, in particular, after $48 \mathrm{~h}$.

The results presented in this section are consistent with the notion that, under these specific experimental conditions, the DNA-damaging response induced by arsenite in U937 cells has nothing to do with the apoptotic degradation processes and is therefore indicative of genotoxicity.

\subsection{Arsenite-induced DNA strand scission is mediated by mitoO $2^{--}$formation and by its downstream product $\mathrm{H}_{2} \mathrm{O}_{2}$}

We next investigated the mechanism associated with the DNA strand scission induced by arsenite. For this purpose, we initially performed a series of experiments using DHR, a general fluorescence probe detecting $\mathrm{O}_{2}{ }^{--}$as well as $\mathrm{H}_{2} \mathrm{O}_{2}$ (32). DHR also detects RNS (33), which however are not produced under the experimental conditions employed (18). The results obtained in these experiments are in keeping with our previous findings $(18,19)$ and indicate that the arsenite $(2.5 \mu \mathrm{M}, 16 \mathrm{~h})$-induced DHR-fluorescence response is abolished by Rot, a complex I inhibitor, the respiration-deficient phenotype, AA and enzymatically active catalase (Fig. 2A). ATZ, while causing an approximate $70 \%$ reduction in catalase activity (data not shown), remarkably enhanced the arsenite-dependent DHR-fluorescence response.

These results confirm our previous findings indicating that arsenite promotes mitoO $_{2}{ }^{-}$ formation, also detected previously through MitoSOX red-fluorescence and aconitase inhibition $(18,19)$. For this reason, and for the observed inhibition mediated by Rot, AA or 
the respiration-deficient phenotype, the possibility that the DHR-fluorescence response is associated with direct effects of arsenite or its metabolites appears unlikely. $\mathrm{MitoO}_{2}{ }^{-}$ formation was associated with its prompt dismutation to $\mathrm{H}_{2} \mathrm{O}_{2}$.

Interestingly, we found that the DNA damage mediated by arsenite was suppressed under conditions associated with prevention of $\mathrm{mitoO}_{2}^{-\cdot}$ formation (Figs. $2 \mathrm{~B}$ and C). The results obtained in these experiments also pointed to a protective effect mediated by enzymatically active catalase. On the other hand, ATZ significantly enhanced the DNA-damaging response induced by arsenite.

In order to establish the specificity of the treatments/manipulations employed to modulate $\mathrm{O}_{2}{ }^{-} / \mathrm{H}_{2} \mathrm{O}_{2}$ formation, we measured their effects on the DHR-fluorescence (Fig. 2D) and DNAdamaging (Figs. 2E and F) responses mediated by reagent $\mathrm{H}_{2} \mathrm{O}_{2}$. The results obtained in these experiments, while confirming the expected protective effects mediated by enzymatically active catalase, and the increased sensitivity associated with the inhibition of cellular catalase activity, show a lack of effect by either Rot or AA. In addition, RD cells were as sensitive as their respiration-proficient counterparts in terms of DHR-fluorescence and DNA strand scission induced by reagent $\mathrm{H}_{2} \mathrm{O}_{2}$. These results provide further evidence of the specificity of the effects mediated by Rot or AA in cells treated with arsenite.

Taken all together, these results show that the DNA-damaging response induced by arsenite is entirely mediated by events leading to the formation of $\mathrm{mitoO}_{2}{ }^{-\cdot}$ and to its dismutation to $\mathrm{H}_{2} \mathrm{O}_{2}$.

\subsection{Arsenite induces CsA-sensitive loss of mitochondrial membrane potential and mitochondrial permeability transition}

The results reported in the previous section are consistent with the notion that $\mathrm{H}_{2} \mathrm{O}_{2}$, once produced after $\mathrm{O}_{2}^{-}$- dismutation, exits the mitochondria, migrates to the nucleus and eventually causes DNA strand scission, likely mediated by hydroxyl radical formation. We next tested 
the possibility that $\mathrm{H}_{2} \mathrm{O}_{2}$ mediates parallel events leading to the formation of additional DNAdamaging species.

Arsenite, as we have previously shown $(18,19,23)$, causes mitochondrial dysfunction. In line with those findings, the results illustrated in Fig. 3A show that a $16 \mathrm{~h}$ exposure to $2.5 \mu \mathrm{M}$ arsenite causes a significant loss of mitochondrial membrane potential. This effect was prevented by the MPT inhibitor CsA (25), with hardly any effect detected with FK-506, which also inhibits calcineurin without any effect on MPT (24) (Fig. 3A). Various treatments/manipulations resulting in inhibition of $\mathrm{mitoO}_{2}^{-}$formation $(18,19)$, e.g., Rot, the respiration-deficient phenotype or AA, also prevented the arsenite-mediated decline in mitochondrial membrane potential.

As the loss of mitochondrial membrane potential is both CsA-sensitive and followed by the onset of toxicity (18), MPT is likely to occur under the above-mentioned conditions. We therefore performed experiments in which MPT pore opening was assessed by monitoring the changes in mitochondrial calcein fluorescence after quenching the cytosolic signal with divalent cobalt. Cells labelled with calcein-AM displayed a bright and uniform fluorescence (not shown) that changed dramatically after the addition of $\mathrm{Co}^{2+}$, as a result of the quenching of cytosolic and nuclear calcein-derived fluorescence. Under these conditions, the resulting images of untreated cells are characterised by a punctuate fluorescence (Fig. 3Ba), similar to the one detected with a mitochondrial probe (not shown), and indeed entirely attributable to mitochondrial calcein, as $\mathrm{Co}^{2+}$ fails to penetrate the mitochondrial membrane (34). It follows that loss of mitochondrial fluorescence, and hence of mitochondrial calcein, is indicative of mitochondrial pore opening. This event was observed in some of the cells exposed for $16 \mathrm{~h}$ to $2.5 \mu \mathrm{M}$ arsenite (Fig. 3Bb). This image should be compared with that shown in Fig. 3Bc, in which the presence of the cells can be observed by darkening the digital image at the expense of brightness. CsA abolished the loss of fluorescence (Fig. 3Bd). Similar results were 
obtained with Rot (Fig. 3Be), the respiration-deficient phenotype (Fig. 3Bf) and AA (not shown), whereas FK-506 was inactive (not shown).

These results show that arsenite induces MPT, a finding which is also consistent with the outcome of experiments measuring the mitochondrial release of cytochrome c determined using an immunocytochemical approach. The punctuate fluorescence observed in untreated cells (Fig. 3Ca) was lost after treatment with arsenite $(2.5 \mu \mathrm{M}, 16 \mathrm{~h})$, and the overall decrease in fluorescence is readily explained by the dilution of cytochrome c released by the mitochondria in the cytosol (Fig. 3Cb). This event was abolished by CsA (Fig. 3Cc). The effect of CsA was mimicked by Rot (Fig. 3Cd), the respiration-deficient phenotype (Fig. 3Ce) and AA (not shown), whereas FK-506 was inactive (not shown).

Finally, we investigated the impact of the metalloid on the energy status of the cells and found evidence of a small decline in cellular ATP (Fig. 3D). This response was abolished by CsA, Rot and AA, with hardly any effect detected after the addition of FK-506 (not shown).

Taken all together, these results show that, under the same conditions in which arsenite promotes $\mathrm{mitoO}_{2}{ }^{--}$formation and downstream DNA strand scission, a significant proportion of the cells, while maintaining elevated ATP levels, display a remarkable and widespread loss of mitochondrial membrane potential associated with MPT.

\subsection{Arsenite-induced DNA strand scission is also mediated by the fraction of CsA- sensitive ROS}

We wondered whether the DHR-fluorescence response mediated by arsenite $(2.5 \mu \mathrm{M}, 16$ h), previously determined as sensitive to Rot, the respiration-deficient phenotype, AA and enzymatically active catalase (Fig. 2A), is also affected by treatments selectively targeting MPT. Interestingly, the outcome of these experiments was in line with the notion that a large fraction of the reactive species is indeed produced via a CsA-sensitive mechanism, with hardly any effect induced by FK-506 (Fig. 4A). We therefore investigated whether these CsA- 
sensitive ROS had any role in the overall processes leading to DNA strand scission. The results obtained in these experiments showed that, regardless of whether the DNA damage was measured with the alkaline halo (Fig. 4B) or the comet (Fig. 4C) assay, CsA, unlike FK506, remarkably reduced the extent of DNA cleavage induced by arsenite.

The possibility that the protective effects of CsA are associated with an antioxidant action was also tested in experiments using $\mathrm{H}_{2} \mathrm{O}_{2}$ to induce DHR oxidation (Fig. 2D and inset to Fig. 4A) and DNA strand scission (Figs. 2E, F and inset to Fig. 4B). Both events were suppressed by enzymatically active catalase (Figs. 2D, E and F), as expected, with hardly any effect detected after the addition of CsA (insets to Fig. 4A and 4B). These results provide further evidence of the specificity of the effects mediated by CsA in cells treated with arsenite.

We then investigated whether the CsA-sensitive fraction of the arsenite-dependent DNA strand scission had any role in the p53 response triggered by DNA damage. More specifically, we used the RT-PCR technique to conveniently monitor p53 mRNA upregulation. The results obtained in these experiments are indicative of an arsenite $(2.5 \mu \mathrm{M}, 12$ h)-dependent p53 expression taking place through a mechanism abolished by Rot and significantly reduced by CsA (Fig. 4D).

Finally, we investigated the generality of the CsA-sensitive effects on DNA strand scission mediated by arsenite. For this purpose, we performed preliminary studies in different cell types to determine their sensitivity to arsenite-dependent DNA cleavage. Similar levels of DNA strand scission were detected in U937 (Nuclear spreading factor $=7.13 \pm 0.56$ ), MCF-7 (Nuclear spreading factor $=6.95 \pm 0.67)$, HT22 (Nuclear spreading factor $=7.04 \pm 0.39)$ and NCTC-2544 (Nuclear spreading factor $=7.25 \pm 0.69$ ) cells exposed to $2.5,4,5$ or $10 \mu \mathrm{M}$ arsenite, respectively. Interestingly, CsA, unlike FK-506, produced inhibitory responses in these different cell types comparable to those detected in U937 cells (about 40-50\% inhibition). 
Taken together, these results indicate that part of the DNA strand scission induced by arsenite in U937 cells, and other cell types, is dependent on secondary events associated with MPT. 


\section{Discussion}

Arsenite is a very widespread environmental pollutant and an established human carcinogen producing cytotoxicity and genotoxicity via different mechanisms (1-3).

In this study, we initially characterised the DNA-damaging response evoked by a $16 \mathrm{~h}$ exposure of U937 cells to the metalloid using both the alkaline halo and comet assays which, although based on different principles, produced substantially similar results (Fig. 1A). The DNA strand scission detected under these conditions was associated with the formation of frank DNA breaks/alkali labile sites, with hardly any contribution by apoptotic DNA degradation processes, which were in fact observed after significantly longer exposure times to the metalloid (Figs. 1D-G). Moreover, the extent of the DNA damage accumulated under these conditions appeared to be particularly elevated. For example, treatment with $2.5 \mu \mathrm{M}$ arsenite produced a level of DNA lesions similar to that resulting from a 30 min exposure to $200 \mu \mathrm{M}$ peroxynitrite (26). Note that peroxynitrite, while immediately decomposing after being added to the culture medium, leads to DNA strand scission via an indirect mechanism causally-linked to the time-dependent (linear for about $30 \mathrm{~min}$ ) $\operatorname{mitoO}_{2}{ }^{-}$formation (26). A level of DNA strand scission comparable to that mediated by $2.5 \mu \mathrm{M}$ arsenite has also been observed after a 10 min treatment with $50 \mu \mathrm{M} \mathrm{H}_{2} \mathrm{O}_{2}$ (35). We also found evidence of a lower susceptibility of other cell types to the arsenite-dependent DNA strand scission, implying a differential effectiveness of secondary mechanisms triggered by the metalloid in different cell types. This finding is consistent with the results of previous studies (36). The reasons for this differential susceptibility are most likely related to events associated with mitoO ${ }_{2}^{-}$formation, for example at the level of $\mathrm{Ca}^{2+}$ mobilization and/or mitochondrial uptake. An additional consideration regards the specific source of ROS generated by arsenite which may, in specific cell types, depend on activation of NADPH-oxidase $(1,37,38)$, or be associated with a mutual recruitment of NADPH-oxidase and mitoO $_{2}^{-\cdot}$ formation (39). 
Thus, the first conclusion we can make is that U937 cells are particularly susceptible to the DNA-damaging effects mediated by arsenite.

Having previously shown $(18,19)$ that, under identical conditions, arsenite selectively triggers the formation of $\mathrm{mitoO}_{2}^{-}$, with hardly any contribution by the NADPH oxidase pathway $(18,19)$, we investigated the involvement of this reactive species in the arsenitedependent strand scission of genomic DNA. For this purpose, we performed parallel experiments demonstrating that Rot abolishes ROS formation as well as the DNA damage induced by arsenite (Figs. 2A-C). We obtained results that were consistent with this notion using cells with intact mitochondria, but characterised by a non-functional respiratory chain, which failed to respond to the metalloid with an increased DHR-fluorescence and DNA strand scission. The same protective effects were observed with AA, which, as we previously reported (21), is effectively taken up by these cells via high affinity SVCT2 and then further accumulated in their mitochondria using a similar transporter, surprisingly working with the same $\mathrm{Km}$ of the plasma membrane counterpart. These observations, readily explained by the fact that mitochondrial SVCT2, unlike the plasma membrane isoform (21), requires very low concentrations of $\mathrm{Na}^{+}$(below $1 \mathrm{mM}$ ) and the virtual absence of $\mathrm{Ca}^{2+}$, provide a rationale for the observed protective effects. Under conditions involving a $10 \mathrm{~min}$ pre-exposure of as low as $10 \mu \mathrm{M}$ AA, the cytosolic levels of the vitamin were kept very low, unlike the mitochondrial concentration, which increased remarkably (21), thereby inhibiting mitochondrial events associated with mitoO $_{2}^{-\cdot}$ formation (18).

The oxidation of DHR and DNA damage were not directly induced by $\mathrm{O}_{2}{ }^{-}$, which fails to exit the mitochondria $(40,41)$, but rather by its dismutation product, $\mathrm{H}_{2} \mathrm{O}_{2}$, which is indeed capable of exiting the mitochondria to then reach distal targets. The proof of concept of the intermediate role of $\mathrm{H}_{2} \mathrm{O}_{2}$ is provided by the outcome of experiments using reagent catalase, which suppressed both effects, by the loss of function of catalase associated with its thermal inactivation and by the enhanced effects observed under conditions of catalase inhibition 
achieved after ATZ addition (Figs. 2A-C). The specificity of the effects mediated by the different treatments/inhibitors was instead demonstrated by experiments in which the cells were exposed to reagent $\mathrm{H}_{2} \mathrm{O}_{2}$ (Figs. 2D-F). Under these conditions, the DHR-fluorescence and DNA-damaging responses mediated by the oxidant were suppressed by enzymatically active catalase, and remarkably enhanced by ATZ, as expected. Importantly, however, Rot, the respiration-deficient phenotype and AA failed to affect the DHR-fluorescence and DNAdamaging responses mediated by reagent $\mathrm{H}_{2} \mathrm{O}_{2}$.

Taken together, these results lead us to a second conclusion, i.e., that the DNA damage mediated by arsenite is entirely dependent on mitochondrial events leading to $\mathrm{O}_{2}^{-}$. formation and to the conversion of this radical to a diffusible and more stable derivative, $\mathrm{H}_{2} \mathrm{O}_{2}$. More specifically, the fraction of $\mathrm{H}_{2} \mathrm{O}_{2}$ escaping degradation mediated by catalase and other enzymes, reaches the nucleus and causes damage to genomic DNA. $\mathrm{H}_{2} \mathrm{O}_{2}$ has been previously reported to cause DNA strand scission via its site-specific interaction with divalent iron (Fenton reaction).

Clearly, the DNA is not the only target of $\mathrm{H}_{2} \mathrm{O}_{2}$, as the site-specific generation of hydroxyl radicals may take place in different microdomains and affect virtually all the biomolecules (42). Hence, $\mathrm{H}_{2} \mathrm{O}_{2}$ may also trigger amplification mechanisms leading to the formation of species causing additional damage to the DNA. The observation that a large proportion of the cells were at the time of DNA damage analysis experiencing a CsA-sensitive decline in mitochondrial membrane potential and MPT (Fig. 3) led us to investigate whether these events were indeed linked to the downstream formation of reactive oxygen species and DNA damage. Experiments demonstrating that CsA remarkably reduces the DHR-fluorescence (Fig. 4A) and DNA strand scission (Figs. 4B and C) induced by arsenite provide important evidence of such a link. The specificity of the effects mediated by CsA was not only established with the use of FK-506, ineffective under identical conditions (Figs. 4A-C), but also by demonstrating that the MPT inhibitor fails to prevent the DHR-fluorescence response 
(inset to Fig. 4A) or DNA strand scission (inset to Fig. 4B) mediated by reagent $\mathrm{H}_{2} \mathrm{O}_{2}$. These results rule out the possibility that the protection afforded by CsA is mediated by a scavenging effect.

These findings lead to a third conclusion, i.e., that arsenite triggers a dynamic process associated with mitoO ${ }^{-} / \mathrm{H}_{2} \mathrm{O}_{2}$ formation and downstream CsA-sensitive MPT-dependent formation of additional DNA-damaging species. From this standpoint, the CsA-sensitive fraction of the DNA damage would be the one produced through the amplification process mediated by MPT in cells possibly, or likely, committed to death.

On the other hand, it is important to note that U937 cells are a highly glycolytic cell line, which maintained an almost intact ATP pool even under conditions of extensive mitochondrial damage (Fig. 3D). Given this premise, we were not surprised to observe that the cells exposed for $16 \mathrm{~h}$ to arsenite were able to trigger energy-dependent processes downstream to of DNA damage, i.e., p53 mRNA up-regulation (Fig. 4D). This effect was suppressed by Rot and significantly reduced by CsA, thereby emphasising the overall importance of mitoO $2 / \mathrm{H}_{2} \mathrm{O}_{2}$, and in particular, of its CsA-sensitive fraction, in the processes leading to increased p53 mRNA expression. Although these effects were observed in U937 cells, which express non-functional p53, we can nevertheless conclude that the MPT-dependent formation of mitoO ${ }_{2}^{-} / \mathrm{H}_{2} \mathrm{O}_{2}$ causes DNA damage and activates the p53 pathway by enhancing its mRNA expression. Several studies provide evidence of a role for an increased p53 protein stability and increased p53 protein expression in arsenite apoptosis (43-45). Future studies should more clearly define, in an appropriate cellular system, the effect of both the MPT-independent and dependent DNA damage in p53 activation/enhanced expression and the specific impact of these pathways in the lethal response mediated by arsenite.

In this study, we also obtained preliminary results indicating that the CsA-sensitive fraction of the DNA damage detected in U937 cells is remarkably similar to that which is observed in MCF-7, HT22 and NCTC-2544 cells, despite their different sensitivity to 
arsenite. This observation is in keeping with the generality of the CsA-dependent effects on arsenite-genotoxicity.

In conclusion, our results show that mitoO $2_{2}^{-} / \mathrm{H}_{2} \mathrm{O}_{2}$ generated by arsenite is directly involved in the site-specific formation of DNA lesions, with potential implications in mutagenesis and carcinogenesis. Under the same conditions, however, mitoO ${ }^{-}{ }^{-} / \mathrm{H}_{2} \mathrm{O}_{2}$ also triggers downstream events promoting further release of additional DNA-damaging species through an MPT-dependent process. MPT therefore represents the cause of the increased overall amount of $\mathrm{H}_{2} \mathrm{O}_{2}$ generated, and CsA consistently reduced its formation and the extent of DNA damage. From this standpoint, the CsA-sensitive DNA strand scission, while strictly defined as a genotoxic response, appears poorly related to arsenite mutagenesis/carcinogenesis and is in fact more likely relevant to the toxic potential of the metalloid. Exploring this possibility may provide new insights into the well-established antileukemic effects of arsenic. 


\section{Conflict of interest}

The authors declare that they have no conflict of interest.

\section{Acknowledgements}

This Research was supported by Ministero dell'Università e della Ricerca Scientifica e Tecnologica, Programmi di Ricerca Scientifica di Rilevante Interesse Nazionale, 2015, (Grant number: 2015MJBEM2-003). 


\section{References}

[1] Flora, S. J. (2011) Arsenic-induced oxidative stress and its reversibility. Free Radic. Biol. Med. 51, 257-281.

[2] Jomova, K., Jenisova, Z., Feszterova, M., Baros, S., Liska, J., et al. (2011) Arsenic: toxicity, oxidative stress and human disease. J. Appl. Toxicol. 31, 95-107.

[3] Flora, S. J. (2016) Arsenic and dichlorvos: Possible interaction between two environmental contaminants. J. Trace Elem. Med. Biol. 35, 43-60.

[4] Schaumloffel, N. and Gebel, T. (1998) Heterogeneity of the DNA damage provoked by antimony and arsenic. Mutagenesis 13, 281-286.

[5] Liu, F. and Jan, K. Y. (2000) DNA damage in arsenite- and cadmium-treated bovine aortic endothelial cells. Free Radic. Biol. Med. 28, 55-63.

[6] Lynn, S., Gurr, J. R., Lai, H. T., and Jan, K. Y. (2000) NADH oxidase activation is involved in arsenite-induced oxidative DNA damage in human vascular smooth muscle cells. Circ. Res. 86, 514-519.

[7] Liu, S. X., Athar, M., Lippai, I., Waldren, C., and Hei, T. K. (2001) Induction of oxyradicals by arsenic: implication for mechanism of genotoxicity. Proc. Natl. Acad. Sci. U S A 98, 1643-1648.

[8] Hei, T. K. and Filipic, M. (2004) Role of oxidative damage in the genotoxicity of arsenic. Free Radic. Biol. Med. 37, 574-581.

[9] Shi, H., Hudson, L. G., Ding, W., Wang, S., Cooper, K. L., et al. (2004) Arsenite causes DNA damage in keratinocytes via generation of hydroxyl radicals. Chem. Res. Toxicol. $17,871-878$

[10] Ding, W., Hudson, L. G., and Liu, K. J. (2005) Inorganic arsenic compounds cause oxidative damage to DNA and protein by inducing ROS and RNS generation in human keratinocytes. Mol. Cell Biochem. 279, 105-112. 
[11] Liu, S. X., Davidson, M. M., Tang, X., Walker, W. F., Athar, M., et al. (2005) Mitochondrial damage mediates genotoxicity of arsenic in mammalian cells. Cancer Res. 65, 3236-3242.

[12] Snow, E. T., Sykora, P., Durham, T. R., and Klein, C. B. (2005) Arsenic, mode of action at biologically plausible low doses: what are the implications for low dose cancer risk? Toxicol. Appl. Pharmacol. 207, 557-564.

[13] Brink, A., Schulz, B., Kobras, K., Lutz, W. K., and Stopper, H. (2006) Time-dependent effects of sodium arsenite on DNA breakage and apoptosis observed in the comet assay. Mutat. Res. 603, 121-128.

[14] Qin, X. J., Hudson, L. G., Liu, W., Ding, W., Cooper, K. L., et al. (2008) Dual actions involved in arsenite-induced oxidative DNA damage. Chem. Res. Toxicol. 21, 1806-1813.

[15] Ruiz-Ramos, R., Lopez-Carrillo, L., Rios-Perez, A. D., De Vizcaya-Ruiz, A., and Cebrian, M. E. (2009) Sodium arsenite induces ROS generation, DNA oxidative damage, HO-1 and c-Myc proteins, NF-kappaB activation and cell proliferation in human breast cancer MCF-7 cells. Mutat. Res. 674, 109-115.

[16] Jiang, X., Chen, C., Zhao, W., and Zhang, Z. (2013) Sodium arsenite and arsenic trioxide differently affect the oxidative stress, genotoxicity and apoptosis in A549 cells: an implication for the paradoxical mechanism. Environ. Toxicol. Pharmacol. 36, 891-902.

[17] Bunderson, M., Coffin, J. D., and Beall, H. D. (2002) Arsenic induces peroxynitrite generation and cyclooxygenase-2 protein expression in aortic endothelial cells: possible role in atherosclerosis. Toxicol. Appl. Pharmacol. 184, 11-18.

[18] Guidarelli, A., Carloni, S., Balduini, W., Fiorani, M., and Cantoni, O. (2016) Mitochondrial ascorbic acid prevents mitochondrial $\mathrm{O}_{2} \cdot^{-}$formation, an event critical for U937 cell apoptosis induced by arsenite through both autophagic-dependent and independent mechanisms. Biofactors 42, 190-200. 
[19] Guidarelli, A., Fiorani, M., Carloni, S., Cerioni, L., Balduini, W., et al. (2016) The study of the mechanism of arsenite toxicity in respiration-deficient cells reveals that NADPH oxidase-derived superoxide promotes the same downstream events mediated by mitochondrial superoxide in respiration-proficient cells. Toxicol. Appl. Pharmacol. 307, $35-44$.

[20] Azzolini, C., Fiorani, M., Cerioni, L., Guidarelli, A., and Cantoni, O. (2013) Sodiumdependent transport of ascorbic acid in U937 cell mitochondria. IUBMB Life 65, 149-153.

[21] Fiorani, M., Azzolini, C., Cerioni, L., Scotti, M., Guidarelli, A., et al. (2015) The mitochondrial transporter of ascorbic acid functions with high affinity in the presence of low millimolar concentrations of sodium and in the absence of calcium and magnesium. Biochim. Biophys. Acta 1848, 1393-1401.

[22] Fiorani, M., Azzolini, C., Guidarelli, A., Cerioni, L., Scotti, M., et al. (2015) Intracellular dehydroascorbic acid inhibits SVCT2-dependent transport of ascorbic acid in mitochondria. Pharmacol. Res. 99, 289-295.

[23] Guidarelli, A., Fiorani, M., Azzolini, C., Cerioni, L., Scotti, M., et al. (2015) U937 cell apoptosis induced by arsenite is prevented by low concentrations of mitochondrial ascorbic acid with hardly any effect mediated by the cytosolic fraction of the vitamin. Biofactors 41, 101-110.

[24] Henke, W. and Jung, K. (1993) Comparison of the effects of the immunosuppressive agents FK 506 and cyclosporin A on rat kidney mitochondria. Biochem. Pharmacol. 46, 829-832.

[25] Halestrap, A. P., Connern, C. P., Griffiths, E. J., and Kerr, P. M. (1997) Cyclosporin A binding to mitochondrial cyclophilin inhibits the permeability transition pore and protects hearts from ischaemia/reperfusion injury. Mol. Cell Biochem. 174, 167-172. 
[26] Guidarelli, A., Tommasini, I., Fiorani, M., and Cantoni, O. (2000) Essential role of the mitochondrial respiratory chain in peroxynitrite-induced strand scission of genomic DNA. IUBMB Life 50, 195-201.

[27] Darr, D. and Fridovich, I. (1986) Irreversible inactivation of catalase by 3-amino-1,2,4triazole. Biochem. Pharmacol. 35, 3642.

[28] Cantoni, O. and Guidarelli, A. (2008) Indirect mechanisms of DNA strand scission by peroxynitrite. Methods Enzymol. 440, 111-120.

[29] Singh, N. P., McCoy, M. T., Tice, R. R., and Schneider, E. L. (1988) A simple technique for quantitation of low levels of DNA damage in individual cells. Exp. Cell Res. 175, 184-191.

[30] Stocchi, V., Cucchiarini, L., Magnani, M., Chiarantini, L., Palma, P., et al. (1985) Simultaneous extraction and reverse-phase high-performance liquid chromatographic determination of adenine and pyridine nucleotides in human red blood cells. Anal. Biochem. 146, 118-124.

[31] Livak, K. J. and Schmittgen, T. D. (2001) Analysis of relative gene expression data using real-time quantitative PCR and the 2(-Delta Delta C(T)) Method. Methods 25, 402-408.

[32] Gomes, A., Fernandes, E., and Lima, J. L. (2005) Fluorescence probes used for detection of reactive oxygen species. J. Biochem. Biophys. Methods 65, 45-80.

[33] Kooy, N. W., Royall, J. A., Ischiropoulos, H., and Beckman, J. S. (1994) Peroxynitritemediated oxidation of dihydrorhodamine 123. Free Radic. Biol. Med. 16, 149-156.

[34] Petronilli, V., Miotto, G., Canton, M., Brini, M., Colonna, R., et al. (1999) Transient and long-lasting openings of the mitochondrial permeability transition pore can be monitored directly in intact cells by changes in mitochondrial calcein fluorescence. Biophys. J. 76, 725-734.

[35] Guidarelli, A., Sciorati, C., Clementi, E., and Cantoni, O. (2006) Peroxynitrite mobilizes calcium ions from ryanodine-sensitive stores, a process associated with the mitochondrial 
accumulation of the cation and the enforced formation of species mediating cleavage of genomic DNA. Free Radic. Biol. Med. 41, 154-164.

[36] Qin, X. J., Hudson, L. G., Liu, W., Timmins, G. S., and Liu, K. J. (2008) Low concentration of arsenite exacerbates UVR-induced DNA strand breaks by inhibiting PARP-1 activity. Toxicol. Appl. Pharmacol. 232, 41-50.

[37] Smith, K. R., Klei, L. R., and Barchowsky, A. (2001) Arsenite stimulates plasma membrane NADPH oxidase in vascular endothelial cells. Am. J. Physiol. Lung. Cell Mol. Physiol. 280, L442-449.

[38] Straub, A. C., Clark, K. A., Ross, M. A., Chandra, A. G., Li, S., et al. (2008) Arsenicstimulated liver sinusoidal capillarization in mice requires NADPH oxidase-generated superoxide. J. Clin. Invest. 118, 3980-3989.

[39] Li, Y. N., Xi, M. M., Guo, Y., Hai, C. X., Yang, W. L., et al. (2014) NADPH oxidasemitochondria axis-derived ROS mediate arsenite-induced HIF-1alpha stabilization by inhibiting prolyl hydroxylases activity. Toxicol. Lett. 224, 165-174.

[40] Murphy, M. P. (2009) How mitochondria produce reactive oxygen species. Biochem. J. 417, 1-13.

[41] Stowe, D. F. and Camara, A. K. (2009) Mitochondrial reactive oxygen species production in excitable cells: modulators of mitochondrial and cell function. Antioxid. Redox Signal. 11, 1373-1414.

[42] Valko, M., Leibfritz, D., Moncol, J., Cronin, M. T., Mazur, M., et al. (2007) Free radicals and antioxidants in normal physiological functions and human disease. Int. J. Biochem. Cell Biol. 39, 44-84.

[43] Chowdhury, R., Chowdhury, S., Roychoudhury, P., Mandal, C., and Chaudhuri, K. (2009) Arsenic induced apoptosis in malignant melanoma cells is enhanced by menadione through ROS generation, p38 signaling and p53 activation. Apoptosis 14, 108123. 
[44] Keim, A., Rossler, O. G., Rothhaar, T. L., and Thiel, G. (2012) Arsenite-induced apoptosis of human neuroblastoma cells requires p53 but occurs independently of c-Jun. Neuroscience 206, 25-38.

[45] Tokumoto, M., Lee, J. Y., Fujiwara, Y., Uchiyama, M., and Satoh, M. (2013) Inorganic arsenic induces apoptosis through downregulation of Ube $2 \mathrm{~d}$ genes and p53 accumulation in rat proximal tubular cells. J. Toxicol. Sci. 38, 815-820. 


\section{Legend to the figures}

Fig 1. Arsenite induces early DNA strand scission independently of the apoptotic DNA fragmentation.

(A) Cells were exposed for $16 \mathrm{~h}$ to increasing concentrations of arsenite. After treatments, the cells were analyzed for DNA damage with the alkaline halo or comet assays. Results represent the means $\pm \mathrm{SD}$ calculated from at least 3 separate experiments. ${ }^{*} P<0.01 ; * * P<$ 0.001, as compared to untreated cells (two-way ANOVA followed by Bonferroni's test). (B) Representative images of microgel-electrophored DNA from cells incubated for $16 \mathrm{~h}$ in the absence or presence of $2.5 \mu \mathrm{M}$ arsenite. After treatments the cells were analyzed with the comet assay and immediately processed for image analysis. (C) Percentage of cells presenting evidence of damaged DNA (with tails) after exposure to the vehicle $(\mathrm{n}=255)$ or $2.5 \mu \mathrm{M}$ arsenite $(n=329)$. Results represent the means \pm SD calculated from at least 3 separate experiments. ${ }^{* *} P<0.001$, as compared to untreated cells (one-way ANOVA followed by Dunnet's test). (D) Representative images of microgel-electrophored DNA from cells incubated for $48 \mathrm{~h}$ in the absence or presence of $2.5 \mu \mathrm{M}$ arsenite. Apoptotic cells display a pear-shaped morphology. (E) Percentage of pear-shaped (apoptotic) cells after treatment with the vehicle $(n=358)$ or arsenite $(n=435)$. Results represent the means \pm SD calculated from at least 3 separate experiments. ${ }^{* *} P<0.001$, as compared to untreated cells (one-way ANOVA followed by Dunnet's test). (F) Percentage of cells presenting condensed chromatin (apoptotic) by the Hoechst assay after treatment for increasing time intervals with the vehicle or arsenite. Results represent the means $\pm \mathrm{SD}$ calculated from at least 3 separate experiments. $* P<0.01 ; * * P<0.001$, as compared to untreated cells (two-way ANOVA followed by Bonferroni's test). (G) Percentage of cells with cleaved caspase-3 after $16 \mathrm{~h}$ or $48 \mathrm{~h}$ exposure 
to arsenite. Results represent the means $\pm \mathrm{SD}$ calculated from at least 3 separate experiments. ** $P<0.001$, as compared to untreated cells (one-way ANOVA followed by Dunnet's test).

Fig 2. Arsenite-induced DNA strand scission is mediated by mitoO ${ }_{2}{ }^{--}$formation and by its downstream product $\mathrm{H}_{2} \mathrm{O}_{2}$.

Cells were exposed for $15 \mathrm{~min}$ to $0.5 \mu \mathrm{M}$ Rot, $10 \mu \mathrm{M}$ AA, $50 \mathrm{U} / \mathrm{ml}$ catalase, or heat inactivated catalase, and incubated for a further $16 \mathrm{~h}$ with $2.5 \mu \mathrm{M}$ arsenite. Alternatively, cells were incubated for $6 \mathrm{~h}$ with 0 or $10 \mathrm{mM} \mathrm{ATZ}$ and subsequently treated with $2.5 \mu \mathrm{M}$ arsenite, as described above. Selected experiments were performed using RD cells. After treatments, the cells were analyzed for DHR-fluorescence (A) or for DNA damage by the alkaline halo (B) or comet assays (C) . In other experiments, the cells were first treated as detailed in panel A and subsequently exposed for $15 \min$ to $75 \mu \mathrm{M} \mathrm{H}_{2} \mathrm{O}_{2}$. After treatments, the cells were analyzed for DHR-fluorescence (D) or DNA damage with the alkaline halo (E) or comet assays (F). Results represent the means \pm SD calculated from at least 3 separate experiments. ${ }^{*} P<0.001 ;{ }^{* *} P<0.0005$, as compared to untreated cells (one-way ANOVA followed by Dunnet's test).

Fig 3. Arsenite induces CsA-sensitive loss of mitochondrial membrane potential and mitochondrial permeability transition.

(A) The cells were exposed for 15 min to Rot, AA, $0.5 \mu \mathrm{M}$ CsA or $1 \mu \mathrm{M}$ FK-506 and incubated for a further $16 \mathrm{~h}$ with $2.5 \mu \mathrm{M}$ arsenite. Selected experiments were performed using RD cells. After treatments, the cells were analyzed for MitoTracker red CMXRosfluorescence. Results represent the means \pm SD calculated from at least 3 separate experiments. ${ }^{* *} P<0.001$, as compared to untreated cells (one-way ANOVA followed by Dunnet's test). (B) Representative images of cells exposed for $16 \mathrm{~h}$ to 0 or $2.5 \mu \mathrm{M}$ arsenite (with the additions indicated in the different images) and treated in the last 30 min with 
calcein-AM associated with $\mathrm{CoCl}_{2}$. Untreated cells are shown in panel a. Panel b shows that arsenite promotes loss of mitochondrial calcein. Panel $\mathrm{c}$ shows the same image in which the presence of the cells is shown by darkening the digital image. Loss of mitochondrial calcein induced by arsenite cells was prevented by CsA (d) or Rot (e). Panel f shows that the $16 \mathrm{~h}$ exposure of RD cells to $2.5 \mu \mathrm{M}$ arsenite fails to induce loss of mitochondrial calcein. The micrographs are representative of at least three separate experiments with similar outcomes. (C) Representative micrographs of cytochrome c immunoreactivity in cells treated with arsenite. Untreated cells, shown in panel a, display a punctuate fluorescence indicative of the mitochondrial location of cytochrome. Panel b shows that exposure to $2.5 \mu \mathrm{M}$ arsenite induces loss of mitochondrial cytochrome c. This effect was prevented by CsA (c) or Rot (d). Panel e shows that the $16 \mathrm{~h}$ exposure of RD cells to $2.5 \mu \mathrm{M}$ arsenite fails to induce loss of mitochondrial cytochrome c. The micrographs are representative of at least three separate experiments with similar outcomes. (D) Cells were exposed for 15 min to Rot, AA or CsA and incubated for a further $16 \mathrm{~h}$ with $2.5 \mu \mathrm{M}$ arsenite. After treatments, the cells were processed for the measurement of the ATP concentrations. Results are expressed as percentages of ATP levels of the control (untreated $21.89 \pm 2.56 \mathrm{nmol} / \mathrm{mg}$ proteins) and represent the means $\pm \mathrm{SD}$ calculated from at least 3 separate experiments. ${ }^{*} P<0.05$, as compared to untreated cells (one-way ANOVA followed by Dunnet's test).

Fig 4. Arsenite-induced DNA strand scission is also mediated by the fraction of the CsAsensitive ROS.

(A-C) Cells were exposed for $15 \mathrm{~min}$ to $0.5 \mu \mathrm{M}$ CsA, or $1 \mu \mathrm{M}$ FK-506, and incubated for a further $16 \mathrm{~h}$ with $2.5 \mu \mathrm{M}$ arsenite. After treatments, the cells were analyzed for DHRfluorescence (A) or DNA damage by the alkaline halo (B) or comet (C) assays. Also shown in the insets are the DHR-fluorescence (A) or the DNA damage (B) detected in cells exposed for 15 min to CsA and then incubated for a further 15 min with $75 \mu \mathrm{M} \mathrm{H}_{2} \mathrm{O}_{2}$. (D) Cells were 
exposed for 15 min to Rot or CsA, and incubated for a further $12 \mathrm{~h}$ with $2.5 \mu \mathrm{M}$ arsenite. After treatments, the cells were processed and analyzed for p53 mRNA expression, as described in the Materials and methods section. Results represent the means $\pm \mathrm{SD}$ calculated from at least 3 separate experiments. ${ }^{*} P<0.01 ;{ }^{*} P<0.001$ as compared to untreated cells. $\left.{ }^{*}\right) P<0.01 ;$ as compared to cells treated with arsenite (one-way ANOVA followed by Dunnet's test). 

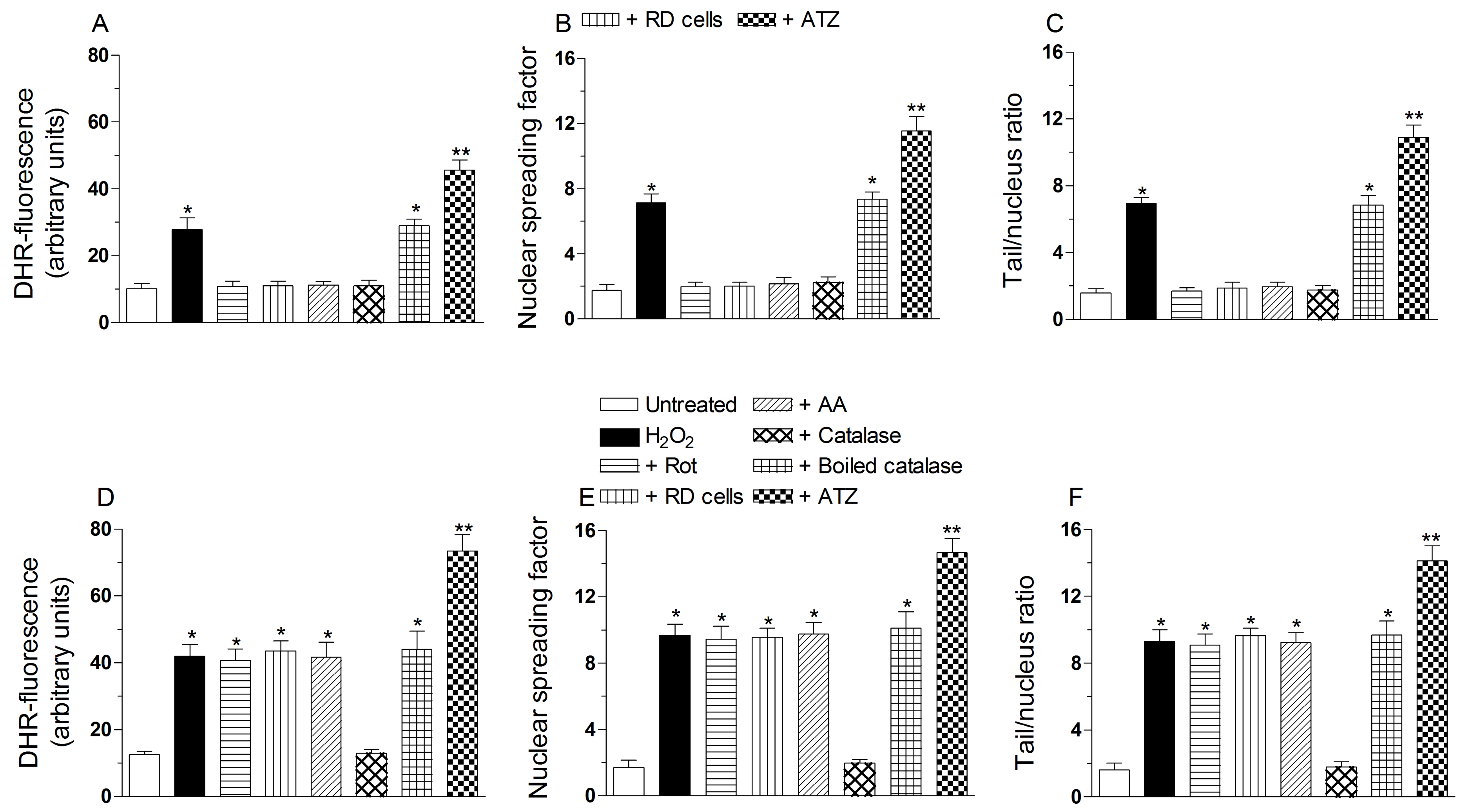
A
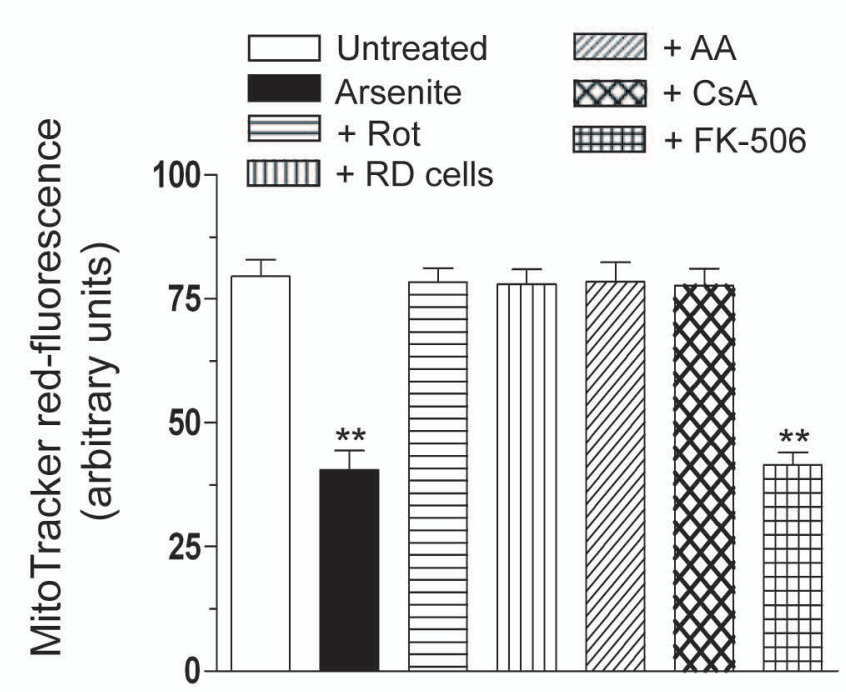

B Untreated

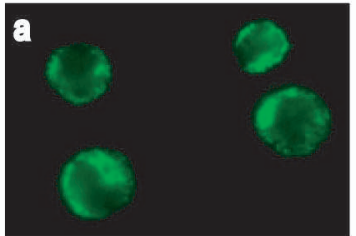

Arsenite

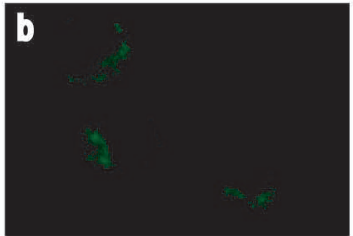

Arsenite

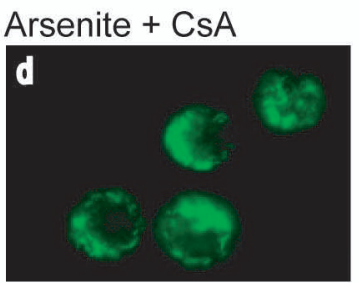

Arsenite + Rot
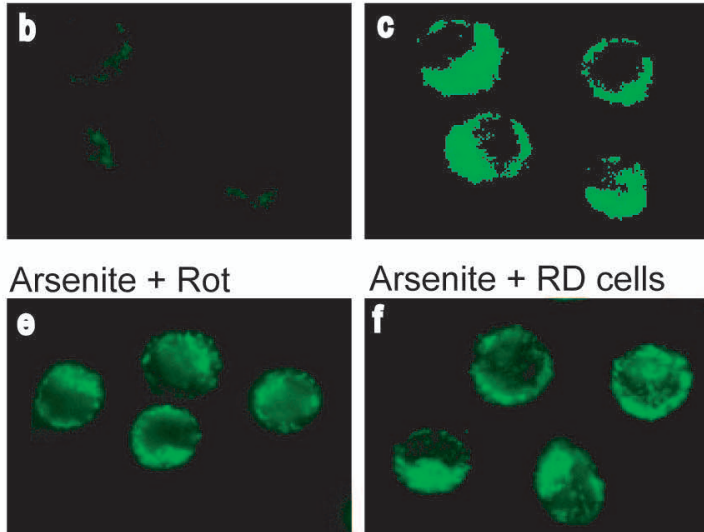

Arsenite + RD cells

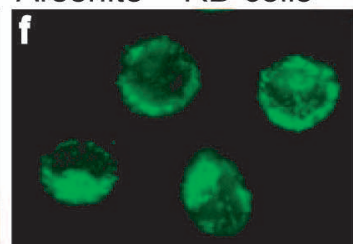

C

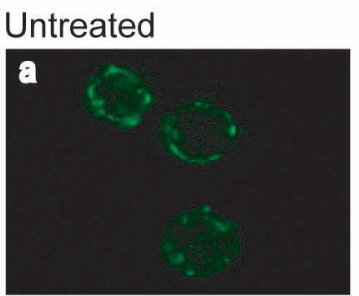

Arsenite

Arsenite + CsA
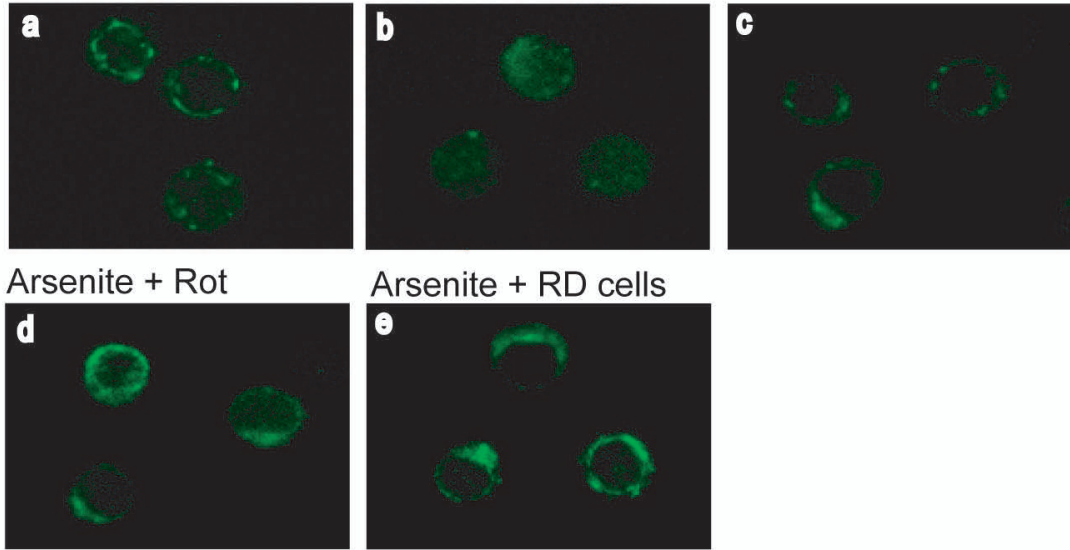

Arsenite + RD cells

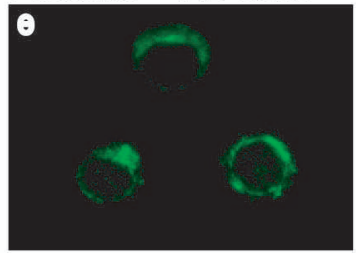

D

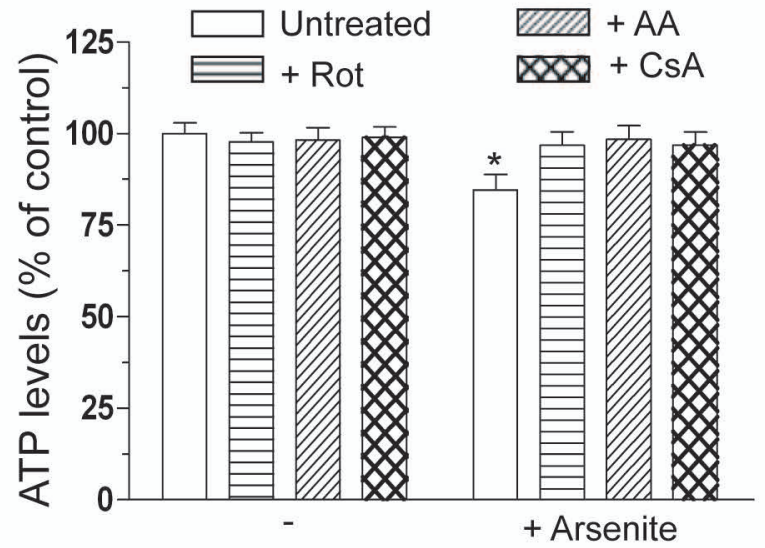

Figure 3 
A $\square$ Untreated

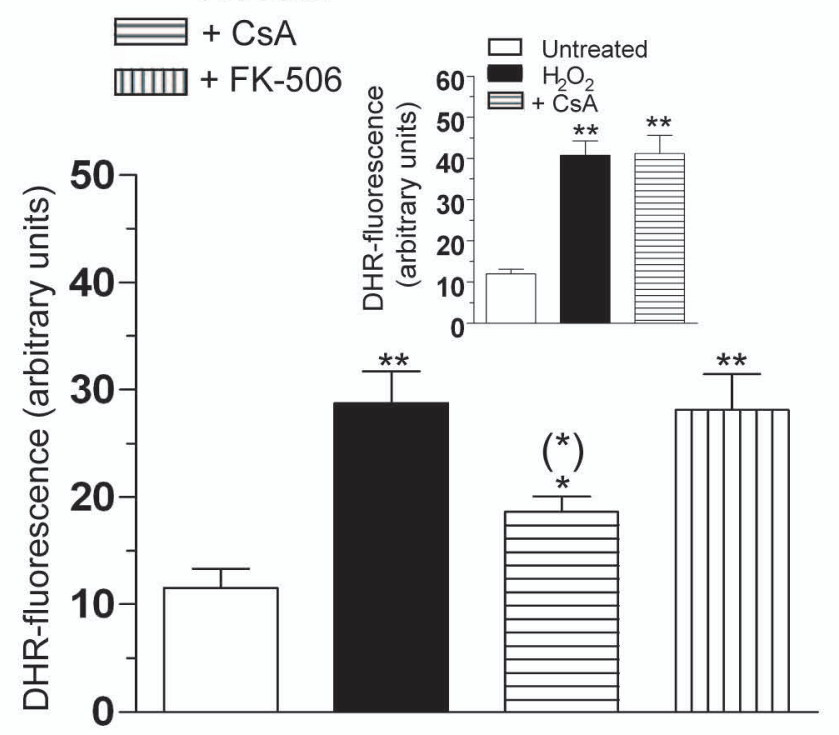

C

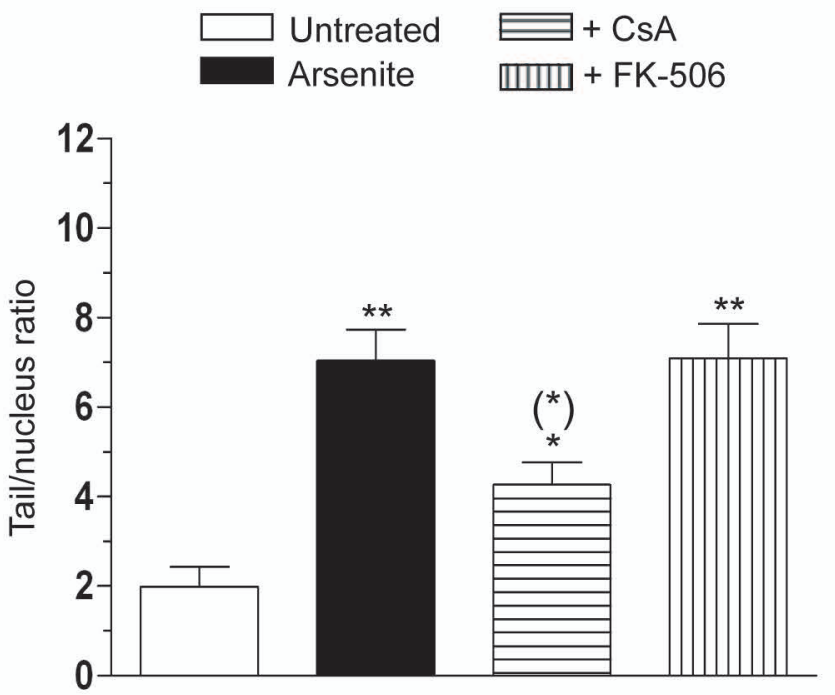

B
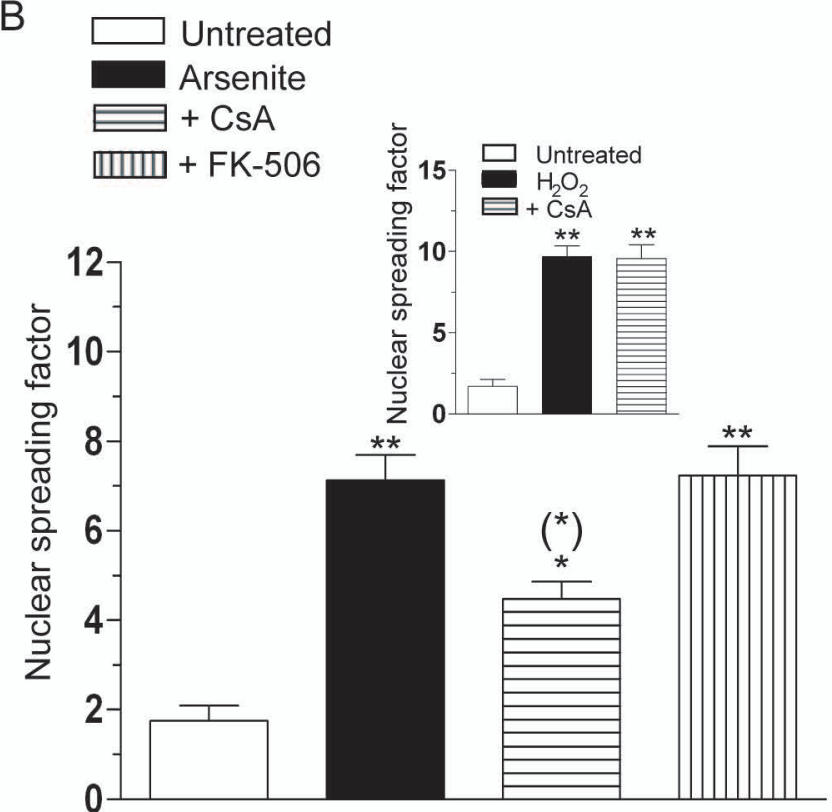

D

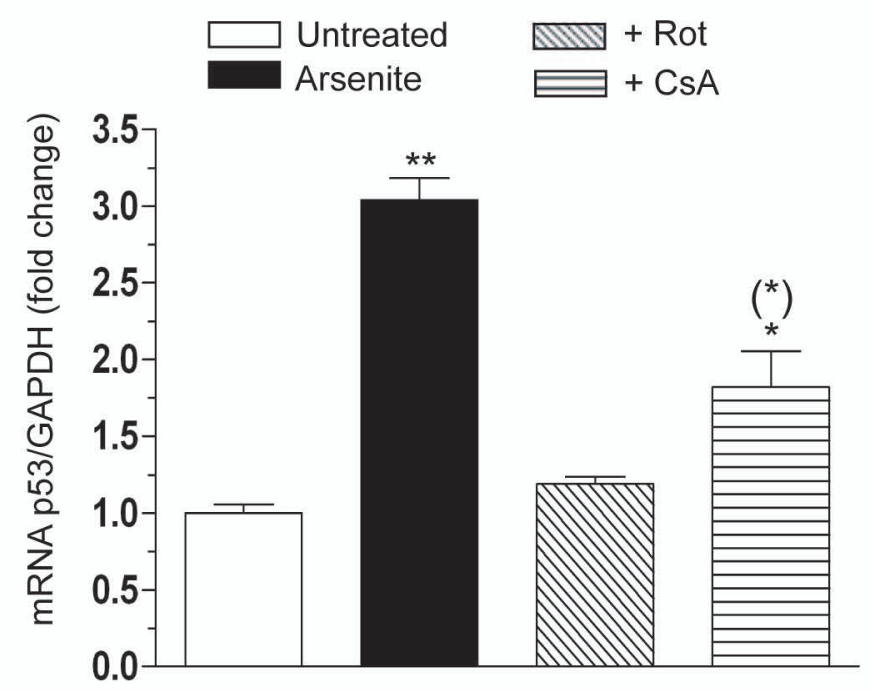

Figure 4 